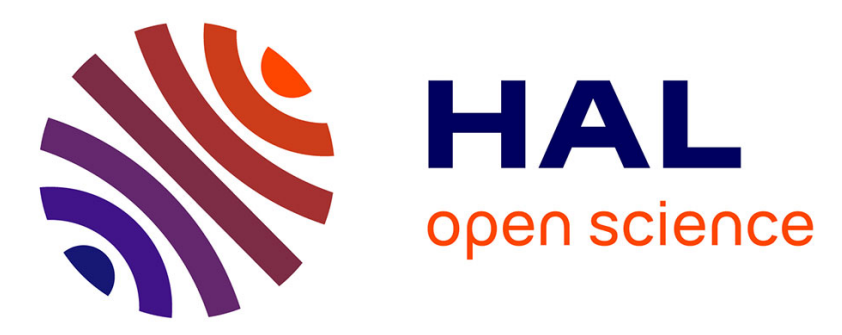

\title{
A MALDI-TOF based study of the in-vivo assembly of glutenin polymers of durum wheat
}

Mariana S. L. Ferreira, Cecile Mangavel, Helene Rogniaux-Bonaventure, Joelle Bonicel, Marie-Francoise Samson, Marie Helene Morel

\section{- To cite this version:}

Mariana S. L. Ferreira, Cecile Mangavel, Helene Rogniaux-Bonaventure, Joelle Bonicel, MarieFrancoise Samson, et al.. A MALDI-TOF based study of the in-vivo assembly of glutenin polymers of durum wheat. Food Research International, 2014, 63, pp.89-99. 10.1016/j.foodres.2013.12.025 . hal-01268922

\section{HAL Id: hal-01268922 \\ https://hal.science/hal-01268922}

Submitted on 27 May 2020

HAL is a multi-disciplinary open access archive for the deposit and dissemination of scientific research documents, whether they are published or not. The documents may come from teaching and research institutions in France or abroad, or from public or private research centers.
L'archive ouverte pluridisciplinaire $\mathbf{H A L}$, est destinée au dépôt et à la diffusion de documents scientifiques de niveau recherche, publiés ou non, émanant des établissements d'enseignement et de recherche français ou étrangers, des laboratoires publics ou privés. 


\title{
Accepted Manuscript
}

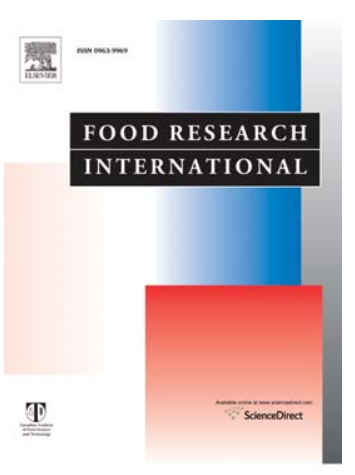

A MALDI-TOF based study of the in-vivo assembly of glutenin polymers of durum wheat

Mariana S.L. Ferreira, Cécile Mangavel, Hélène Rogniaux, Joëlle Bonicel, Marie-Françoise Samson, Marie-Hélène Morel

\author{
PII: $\quad$ S0963-9969(13)00679-0 \\ DOI: $\quad$ doi: $10.1016 /$ j.foodres.2013.12.025 \\ Reference: $\quad$ FRIN 4985 \\ To appear in: $\quad$ Food Research International \\ Received date: 13 August 2013 \\ Accepted date: 19 December 2013
}

Please cite this article as: Ferreira, M.S.L., Mangavel, C., Rogniaux, H., Bonicel, J., Samson, M.-F. \& Morel, M.-H., A MALDI-TOF based study of the in-vivo assembly of glutenin polymers of durum wheat, Food Research International (2013), doi: $10.1016 /$ j.foodres.2013.12.025

This is a PDF file of an unedited manuscript that has been accepted for publication. As a service to our customers we are providing this early version of the manuscript. The manuscript will undergo copyediting, typesetting, and review of the resulting proof before it is published in its final form. Please note that during the production process errors may be discovered which could affect the content, and all legal disclaimers that apply to the journal pertain. 


\section{A MALDI-TOF based study of the in-vivo assembly of glutenin polymers of durum}

\section{wheat}

Mariana S. L. Ferreira $^{\mathrm{a} 1}$, Cécile Mangavel ${ }^{\mathrm{b} 2}$, Hélène Rogniaux ${ }^{\mathrm{b}}$, Joëlle Bonicel $^{\mathrm{a}}$, MarieFrançoise Samson ${ }^{\mathrm{a}}$, Marie-Hélène Morel $^{\mathrm{a}}{ }^{*}$

${ }^{a}$ INRA, UMR1208 Agropolymers Engineering and Emerging Technologies, 2 place Pierre Viala, F-34060 Montpellier, France.

b INRA, UR1268 Biopolymers Interactions Assemblies, Rue de la Géraudière, F-44316 Nantes, France.

* Corresponding author: Tel: +33 4996125 62. Email: marie-helene.morel@ supagro.inra.fr

Authors e-mail: mariana.ferreira@unirio.br; cecile.mangavel@univ-lorraine.fr; helene.rogniaux@nantes.inra.fr; bonicelj@supagro.inra.fr; mariefrancoise.samson@supagro.inra.fr; marie-helene.morel@supagro.inra.fr

\footnotetext{
${ }^{1}$ Present address: Federal University of Rio de Janeiro State (UNIRIO), Food and Nutrition Master Program (PPGAN), Laboratory of Protein Biochemistry (LBP), Av. Pasteur, 296, 22290-180, Rio de Janeiro, Brazil.

${ }^{2}$ ENSAIA-INPL, 2 Avenue de la Forêt de Haye, 54505, BP 172, Vandoeuvre lès Nancy, France.
} 


\section{Abstract}

Wheat grain is recognized as the most suitable raw material for bread and pasta making due to the unique viscoelasticity of its storage proteins, and in particular its glutenin polymers. During grain development, low molecular weight (LMW) and high molecular weight (HMW) glutenin subunits (GS) gradually assembled through inter-chain disulfide bonds. Despite the impact of the final glutenin polymers size distribution on wheat technological quality, little is known concerning the oxidative folding of GS. In particular, which of their cysteine residues (Cys) participate to GS inter-chains remains putative. In this study GS from immature T. durum wheat grain were separated (1D SDS-PAGE) and digested into peptides, which were analysed by MALDI-TOF/TOF. Differential alkylation of free and disulfide bonded Cys allowed us to identify the oxidative folding state of five types of LMW-GS and of the 1Bx20 HMW-GS. GS as monomers or as part of small oligomers carried a high number of free cysteine residues. In addition, some Cys residues, hitherto assumed as involved in intra-chain disulfide bonds, appeared simultaneously in free and oxidized forms. The last result could be assigned to their partial-blocking by glutathione. We concluded that the complete oxidative folding of LMW-GS is a late event, subsequent to GS inter-chain pairing.

Keywords: Durum wheat, cysteine, redox state, grain development, glutenin polymers, MALDI-TOF.

Abreviations $^{3}$

\footnotetext{
${ }^{3}$ 1D SDS-PAGE: One dimensional-Sodium Dodecyl Sulfate Polyacrylamide Gel Electrophoresis; 4VP 4-Vynil pyridylethyl; ACN: Acetonitrile; Cys: Cysteine; Cys-CAM: Carbamidomethyl-cysteine; Cys-PAM: Propionamide-cysteine; Cys-PE: 4-Vynil pyridylethyl-cysteine; Cys-NEM: Nethylmaleimide-cysteine; DHB: Dihydroxybenzoic acid; HCCA: a-cyano-4-hydroxycinnamic acid; HMW-GS- High Molecular Weight Glutenin Subunits; IAM: Iodoacetoamide; INRA: National Institute for Agricultural Research; LMW-GS- Low Molecular Weight Glutenin Subunits; MALDITOF- Matrix Assisted Laser Desorption Ionization - Time of flight; Mr: Relative molecular mass; MS: mass spectrometry; NEM: N-ethylmaleimide; PMF: peptide mass fingerprinting; PSH: Protein sulfhydryl groups; RP-HPLC: Reversed Phase- High Performance Liquid Chromatography; SA:
} 


\section{Introduction}

Amongst the cereal grain species produced and consumed by human beings, wheat is the only one easily transformed into pasta and leavened baked products because of the unique viscoelastic properties of its storage proteins. The latter includes monomers (gliadin) and polymers (glutenin) with a roughly 50:50 weight distribution. Polymeric structure of glutenin arises from the disulfide bonding of low molecular weight (LMW) and high molecular weight (HMW) polypeptides, herein referred as glutenin subunits (GS). GS typically carry 2 to 8 cysteines residues (Cys) including two to three that would form inter-chain linkages. In contrast, Cys of gliadin polypeptides are in an even number and all involved into stable intrachain disulfide bonds.

The formation of inter-chain disulfide bonds between GS is a post-translational event essential for their assembly into polymers. Nevertheless in wheat, the relationship between the functionality and structure of these polymers is still poorly understood. Cereal chemists agree that the number and position of Cys within the polypeptide primary sequence should impact GS ability to form inter-chain disulfide bonds, whereas relative proportion of the different GS should affect the final polymer structure. Hence, the number of Cys per GS able to form interchain disulfide bonds will decide on the linear or branched structure of glutenin polymers. Despite the impact of the glutenin polymers size distribution on wheat technological quality (Naeem \& MacRitchie, 2005; Popineau et al., 1994), the arrangement of inter-chain pairing of cysteine and their position in the GS sequences are largely ignored.

Sinapinic acid; SE-HPLC: Size Exclusion High Performance Liquid Chromatography; TFA: trifluoroacetic acid. 
Unraveling the intimate architecture of glutenin polymers is a challenging goal since GS include numerous polypeptides sharing strongly homologous sequences. Indeed, while HMW-GS include a small number of easily identifiable polypeptides of high molecular weight $(70,000-90,000)$, LMW-GS consists of a multigenic family of numerous proteins of smaller polypeptides $(20,000-45,000)$ that overlap gliadin, making difficult their proper identification. The allopolyploïd nature of the wheat genome which leads to orthologous loci further complicates the scenario.

The most detailed investigations about the mapping of GS disulfides bonds were carried out by H. Wieser and collaborators (Keck et al., 1995; Köhler et al., 1993; Müller et al., 1998). They submitted isolated glutenin from mixed water/dough to partial hydrolysis, hence identified cystine containing peptides by differential Reversed Phase- High Performance Liquid Chromatography (RP-HPLC) analysis under reduced or non-reduced conditions, and finally submitted them to automated Edman degradation. The amino-acid sequences of peptides were then assigned to known GS sequences. From this huge work, maps of Cys pairing were proposed and disulfide bonds formation assumed as highly targeted (Müller et al., 1998). In particular, it was established that LMW-GS contain two Cys that are likely to be involved in an inter-chain disulfide bond, i.e. the first $\left(C^{b}\right)$ and the seventh $\left(C^{x}\right)$. Amino-acid sequence analysis showed that these residues are surrounded by flexibility areas, which could promote the glutenin polymerization (D'Ovidio \& Masci, 2004; Masci et al., 1998). The other six Cys, common to most of LMW-GS are expected to be involved in intra-chain disulfide bonds.

To the best of our knowledge, since the 2000s and the introduction of modern proteomic technology, no additional data has been released on that topic, despite the powerfulness of mass spectrometry (MS) for establishing disulfide bond mapping in proteins (Alvarez et al., 
2009; Bloom et al., 2002; Foley et al., 2008; Schnaible et al., 2002; M. Zhang \& Kaltashov, 2006).

Another approach addressing glutenin disulfide pairings concerns the study of native or modified GS expression in transgenic plants (Shani et al., 1992). The expressed polypeptides were characterized by SDS-PAGE under reduced or non-reduced conditions, and then detected by using GS specific anti-sera (Lombardi et al., 2009; Shani et al., 1994; Shani et al., 1992). Several oligomer configurations were observed and they concluded that inter-chain disulfide pairings of GS lack of specificity. Additionally, an intra-chain disulfide bonds between two highly conserved Cys $\left(\mathrm{C}^{\mathrm{c}}-\mathrm{C}^{\mathrm{f} 1}\right)$ of LMW-GS was found mandatory to prevent aberrant GS aggregation (Lombardi et al., 2009).

More recent approaches focused on the biochemical events accompanying glutenin polymerization during wheat grain development (Ferreira et al., 2012a; Ferreira et al., 2012b; Rhazi et al., 2003; Shewry et al., 2009). Protein sulfhydryl groups (PSH) from immature grains were labelled by specific fluorescent probes and storage protein were identified by SDS-PAGE and RP-HPLC (De Gara et al., 2003; Ferreira et al., 2009; Gobin et al., 1997; Rhazi et al., 2003). Only glutenin, in both monomeric and polymeric form, was labelled indicating that gliadin polypeptides readily undergone oxidative folding.

For Triticum aestivum, the relative amount of fluorescent labelled GS highly increased during the enlargement phases of grain development. The fluorescence associated to GS rapidly decreases after the onset of the desiccation phase. At that time, the rate of glutenin polymer formation further increased but above all large SDS-insoluble glutenin polymers (De Gara et al., 2003; Gobin et al., 1997; Rhazi et al., 2003). In contrast, at the first phases of T. durum grain development, glutenin polymer accumulation increased as PSH content dropped. Furthermore, polymers accumulation coincidently stopped with the onset of the grain 
desiccation phase, during which only slight increase in the mean size of glutenin polymers was observed (Ferreira et al., 2009; Ferreira et al., 2012b).

These contrasted results point to different glutenin polymer assemblies for T. aestivum and T. durum. Both species differed in respect to their LMW-GS/HMW-GS ratio, in T. durum, LMW-GS accounts for 80 to $90 \%$ of the total glutenin, compared with 55 to $75 \%$ in $T$. aestivum. Due to their tetraploid nature, durum specie includes a lower number of GS variants and can be considered as prime candidate to establish the dynamic of LMW-GS assembly into glutenin polymers.

In the present study we focused on the redox state of nascent LMW-GS and in particular on the intra-chain disulfide bonds. The rapid oxidative folding of GS would leave in the reduced state only the Cys involved in inter-chain disulfide bonds. Hence, a directed GS inter-chain pairings could be inferred. To gain a deep insight into the dynamic of LMW-GS assembly into polymers, a Matrix Assisted Laser Desorption Ionization - Time of Flight (MALDI-TOF) in tandem analysis was used to investigate the redox state of storage proteins from immature durum wheat grains. Based on the differential alkylation of the glutenin Cys, the mass spectrometry analysis allowed, not only the identification of storage proteins and the oligomers composition, but also the redox status of cysteine from newly synthesized GS. Glutenin polymer formation is discussed in relation to the oxidative folding of the nascent subunits.

\section{Material and Methods}

\subsection{Plant materials}

Cultivar Orlu (Triticum turgidum L. var. durum Desf.) possessing HMW-GS 1B 20x+20y and expressing LMW-GS type 2 was grown in INRA experimental fields (Mauguio, Southern France). Thermal time accumulation $\left({ }^{\circ} \mathrm{Cd}\right)$ was calculated from daily average temperature 
hourly recorded. Several immature spikelets were harvested at 330 and $470{ }^{\circ} \mathrm{C}$ days after anthesis $\left({ }^{\circ} \mathrm{Cd}\right)$. Grains were sampled, freeze-dried and protein sulfhydryl groups (PSH) (typically about $3 \mu$ moles/g grain) was determined as described in Ferreira et al. (2012b).

\subsection{Strategy}

An overview of the strategy used to identify the PSH status of GS and oligomers is given in Figure 1. Total or sequentially extracted protein from immature grains were alkylated with iodoacetamide (IAM) allowing the conversion of reduced cysteine to Cys-CAM. Protein were sequentially fractionated in various solvents and separated by SDS-PAGE under non-reducing condition. Protein bands of interest were submitted to in-gel reduction and alkylation with 4vinyl-pyridine (4-VP) to label the cysteine released from the disulfide bonds (Cys-PE). After trypsin digestion, cysteine-containing peptides (Cys-CAM and Cys-PE) were identified by MALDI-TOF/TOF through mass changes associated with the different alkylating agents used.

\subsection{PSH alkylation and extraction of proteins}

All steps were carried out in dark and at room temperature (RT). Centrifugations were performed at $10,600 \mathrm{x}$ g during $10 \mathrm{~min}$ at $20^{\circ} \mathrm{C}$ unless otherwise specified. Modification of PSH was performed at $100 \mathrm{mg} / \mathrm{mL}$ on $20 \mathrm{mg}$ of ground grains placed within Eppendorf tubes.

\subsubsection{PSH alkylation}

Alkylation was performed using large molar excess of reactants, i.e. $185 \mathrm{mM}$ iodoacetamide (IAM) in $80 \mathrm{mM}$ Tris-HCl buffer (pH 8.0) or $20 \mathrm{mM}$ N-ethylmaleimide (NEM) in $80 \mathrm{mM}$ sodium phosphate buffer ( $\mathrm{pH}$ 6.8) eventually supplemented with $2 \%$ SDS. Samples were shaken for 60 minutes. Alkylated samples were subjected to a sequential extraction, whereas SDS soluble samples were used to the total protein extraction. Based on the different effectiveness, IAM was used at a 9.5 greater concentration than NEM (Rogers et al., 2006).

\subsubsection{Extractions}


Alkylated samples were immediately centrifuged to recover the total SDS-soluble proteins (in the presence of $2 \% \mathrm{SDS}$ ) or the buffer soluble protein fraction. For the latter, pellets were suspended with $200 \mu \mathrm{L}$ of $70 \%$ (v/v) ethanol (EtOH) and agitated for $15 \mathrm{~min}$. EtOH soluble proteins were then recovered by centrifugation. The remaining pellet was extracted with $2 \%$ SDS (w/v) in $80 \mathrm{mM}$ Tris- $\mathrm{HCl}$ buffer $(\mathrm{pH}$ 6.8) under $1 \mathrm{~h}$ agitation and SDS-soluble proteins were obtained after centrifugation.

Extracts were precipitated with 5 volume of cold acetone, centrifuged at $4{ }^{\circ} \mathrm{C}$ and then stored $\left(-18^{\circ} \mathrm{C}\right)$. Differently, the first extract was washed twice with $80 \%$ cold acetone and centrifuged at $4{ }^{\circ} \mathrm{C}$ before storage, in order to remove excess of alkylating agent. All recovered protein extracts were diluted once with TFA $0.1 \%$ and then stored at $-18^{\circ} \mathrm{C}$ before further Size Exclusion-High Performance Liquid Chromatography (SE-HPLC) analysis.

\subsection{Protein fractionation}

\subsubsection{SE-HPLC}

Extracts $(150 \mu \mathrm{L})$ were diluted once with $0.1 \mathrm{M}$ sodium phosphate $(\mathrm{pH}$ 6.8) including $1 \%$ SDS. Twenty $\mu \mathrm{L}$ was injected on a TSK gel G4000SWXL column (Tosoh Bioscience, Sigma Aldrich) equilibrated at RT with $0,1 \%$ SDS in $0.1 \mathrm{M}$ phosphate (pH 6.8). Elution was performed at $0.7 \mathrm{~mL} \cdot \mathrm{min}^{-1}$ and UV (214 nm) signal was recorded. Protein contents of injected extracts were estimated from the integrated $214 \mathrm{~nm}$ UV elution traces using an experimentally established conversion factor (see Morel et al., 2000 for details).

\subsubsection{SDS-PAGE}

The protein extracts were fractionated by SDS-PAGE (13.5\% acrylamide) under reducing and non-reducing conditions using Laemmli protocol. Acetone protein pellets where directly suspended in SDS-PAGE loading buffer (62.5 mM Tris-HCl (pH 6.8), 2\% SDS (w/v), 10\% glycerol (v/v) and $0.1 \%$ bromophenol blue (w/v)) with or without $5 \%$ of $\beta$-mercaptoethanol. 
In the first case, samples were boiled at $100^{\circ} \mathrm{C}$ for $2 \mathrm{~min}$. Amount of $60 \mu \mathrm{g}$ and $40 \mu \mathrm{g}$ of protein were loaded under non reduced and reduced SDS-PAGE conditions, respectively. Electrophoresis run at $20 \mathrm{~mA}$ until the tracking dye reached the bottom of the gel.

\subsection{Sample preparation for MALFI-TOF analysis}

\subsubsection{Protein reduction and second alkylation step}

Bands were manually excised from SDS-PAGE gels. Gel pieces were gentle agitated for $1 \mathrm{~h}$ at RT with $100 \mu \mathrm{L}$ of $25 \mathrm{mM} \mathrm{NH} \mathrm{HCO}_{3}$ and after with $100 \mu \mathrm{L}$ of $25 \mathrm{mM} \mathrm{NH}_{4} \mathrm{HCO}_{3}$ and acetonitrile $(\mathrm{ACN})(50: 50, \mathrm{v} / \mathrm{v})$. After liquid removal, disulphide bonds were reduced with $100 \mu \mathrm{L}$ of $10 \mathrm{mM}$ dithiothreitol (DTT) in $25 \mathrm{mM} \mathrm{NH}_{4} \mathrm{HCO}_{3}$ at $50^{\circ} \mathrm{C}$ under agitation in the dark. After liquid removal, alkylation was performed in $100 \mu \mathrm{L}$ of $50 \mathrm{mM} 4-\mathrm{VP}$ in $25 \mathrm{mM}$ $\mathrm{NH}_{4} \mathrm{HCO}_{3}$ at $\mathrm{RT}$ for $45 \mathrm{~min}$ in the dark. Gel pieces were washed with $200 \mu \mathrm{L}$ of $25 \mathrm{mM}$ $\mathrm{NH}_{4} \mathrm{HCO}_{3}$ for 30 min under gentle agitation and subsequently with $200 \mu \mathrm{L}$ of $25 \mathrm{mM}$ NH4HCO3 and ACN (50:50, v/v) for $15 \mathrm{~min}$. Gel pieces were collected and briefly dehydrated with $100 \mu \mathrm{L}$ of $100 \% \mathrm{ACN}$ for $5 \mathrm{~min}$.

\subsubsection{In-gel digestion of proteins}

Proteins in gel pieces were digested with $20 \mu \mathrm{L}$ of porcine trypsin (Promega) $(7.5 \mathrm{ng} / \mu \mathrm{L})$ in $25 \mathrm{mM} \mathrm{NH}_{4} \mathrm{HCO}_{3}$ at $37^{\circ} \mathrm{C}$ for $3 \mathrm{~h}$ in the dark. To improve the enzyme action, $0.025 \%$ of the surfactant agent ProteaseMAX (Promega) was added. The digestion was stopped by $1 \mu \mathrm{L}$ of $1 \%$ formic acid. Peptides were extracted from the gel with $50 \mu \mathrm{L}$ of $70 \%$ ACN, $10 \%$ formic acid in water for 15 min under sonication (Sonicater 88155, Bioblock Scientific). After centrifugation, the supernatant was recovered and the gel pieces were washed again with 50 $\mu \mathrm{L}$ of $\mathrm{ACN}$ for 15 min under sonication. Both supernatants were dried under reduced pressure (Speed-Vac, $60 \mathrm{~min}, 100 \mathrm{mbar}$ at $30^{\circ} \mathrm{C}$ ). 


\subsection{Mass spectrometry analysis}

\subsubsection{MALDI-TOF/TOF experiments}

A MALDI-TOF/TOF Autoflex III Smartbeam (Bruker-Daltonics, Bremen, Germany) was operated in both linear and reflectron mode. In linear mode $(\mathrm{m} / \mathrm{z}$ range of 5000-100000 Da), the matrix used was composed of $10 \mu \mathrm{g} / \mu \mathrm{L}$ of sinapinic acid (SA) in $50 \%$ (v/v) $\mathrm{ACN}$ and in the reflectron mode $(\mathrm{m} / \mathrm{z}$, range of 500-4000 Da) of $10 \mu \mathrm{g} / \mu \mathrm{L}$ of a-cyano-4-hydroxycinnamic acid (HCCA) and 2, 5-dihydroxybenzoic acid (DHB) in 15mM ammonium phosphate and ACN (30:70, v/v) containing 0.1\% TFA. A sample/matrix solution $(1 \mu \mathrm{L}, 1: 1 \mathrm{v} / \mathrm{v})$ was deposited onto the MALDI sample probe.

\subsubsection{Databank searches and MS/MS analyses}

Following MS acquisition, each spectrum was submitted to a peptide mass fingerprint (PMF) search against the Uniprot sequence databanks using Mascot V.2.2 search engine (Matrix Science). The mass tolerance was set at $75 \mathrm{ppm}$ and one missed cleavage per peptide was allowed. Cysteine modifications such as Carbamidomethylation (Cys-CAM), N-ethylmaleimide (Cys-NEM) and Pyridylethylation (Cys-PE) were selected as fixed modifications and Propionamide (Cys-PAM) and oxidation of methionine (+16 Da) as variable modifications.

Samples that were not unambiguously identified by PMF were further submitted to MS/MS (LIFT TOF/TOF) acquisition, and MS/MS data confronted to an additional search against Uniprot. The mass tolerance was set at 1.0 Da for precursor ion and 0.5 Da for fragment ions. To confirm the sequence of cysteine-containing peptides, MS/MS spectra were submitted to the denovo sequencing (RapidDeNovo BioTools software, Bruker Daltonics). Sequences identified through these databank searches were considered as valid hits when at least four non redundant peptides were found to match a single Uniprot reference with a significant 
score (i.e. above the significance threshold of the MASCOT program, $p<0.05$ ). Cys were numbered according to their position in the primary sequence or using the nomenclature of Köhler et al. (1993).

\section{Results}

\subsection{Fractionation of alkylated storage protein from immature grains}

Sequential extracts from immature grains $\left(330-470^{\circ} \mathrm{Cd}\right)$ were separated by electrophoresis allowing proteins to be categorized owing to their specific $M r$ and solubility (Fig.2A-B). Typical LMW-GS type B subunits were identified without ambiguity by the two characteristic heavy bands $\left(45,000-50,000 M_{\mathrm{r}}\right)$ under reducing condition (Fig.2B). It can be noticed that non-reduced LMW-GS migrated closer to their proper molecular weight $\left(35,000-45,000 M_{\mathrm{r}}\right)$ (Fig.2A). It is assumed that opening intra-chain disulfide bonds allows polypeptides to adopt a more extended structure resulting in an increase of band friction during migration (Lombardi et al., 2009).

Reduction increased bands intensity, indicating the presence of glutenin polymers that could not enter in the gel. In support to this interpretation, it can be noticed that for the SDS-soluble extracts, the protein material trapped at the top of the gel as well as many bands over 85,000 $M r$ disappeared after reduction. Contrarily, the staining of LMW-GS and HMW-GS bands became strongly intensified. For the EtOH extracts, the faint bands over 65,000 $\mathrm{Mr}$ disappeared after reduction, whereas the relative amount of LMW-GS increased. From these results, it can be inferred that small homo-oligomers of LMW-GS were extractible with EtOH. Meanwhile, SDS buffer was required to bring into solution larger species including HMW-GS. In addition, it can be underlined that EtOH extract from $470^{\circ} \mathrm{Cd}$ samples included more oligomers than $330^{\circ} \mathrm{Cd}$ samples. Despite this difference, the effect of grain development was minor. 
In both SDS-PAGE conditions, subtle migration shifts were observed for some LMW-GS bands according to the alkylating agent (see LMW-GS 2 and 4, Fig.2A). In accordance with the molecular weight of the respective adducts, a higher weight increment can be expected after PSH alkylation with NEM compared to IAM. Apart from that, very similar patterns were obtained using $20 \mathrm{mM}$ NEM or $185 \mathrm{mM}$ IAM, indicating similar PSH alkylation effectiveness.

Patterns of LMW-GS bands were more complex in non-reducing condition (up to 4 bands) than in the reduced counterpart ( 2 bands). On the basis of apparent $M r$, different sequential extracts seemed to share same bands. Without anticipating the MALDI-TOF results, we may indicate that the numbering we adopted for the 4 selected LMW-GS bands corresponded to identical polypeptides, whatever the protein extract or the grain development time.

Protein alkylation was also performed within SDS buffer to promote PSH exposure and ensure full alkylation. The electrophoretic patterns of total protein extracts in non-reducing condition were very similar (Fig.3). Bands related to oligomers were clearly evidenced. In the LMW-GS area, bands 1 and 2 were evident while band 3 and 4 were not clearly distinguishable.

\subsection{MALDI-TOF analysis}

MALDI-TOF is a high throughput technology for analyzing proteins primary sequence and is currently the most efficient method, requiring only 4-5 minutes per sample. MALDI ionization essentially generates monocharged ions and thus do not require any deconvolution step. Recently, it has emerged as an alternative technique to characterize wheat storage proteins with high resolution and accuracy (Gao et al., 2010; Liu et al., 2010; Q. Zhang et al., 2008). In this study, grain proteins were separated by one-dimensional electrophoresis and MALDI-TOF was chosen due to its high sensitivity, ability to analyze complex mixtures and 
its tolerance to relatively high concentrations of contaminants, such as solvents, salts and detergents (SDS).

Bands of interest (delineated by frames in Fig.2A and 3) were submitted to MALDI-TOF analysis according to Figure 1. Using IAM as the first alkylating reagent led to a greater number of recovered cystein-containing peptides, in consequence only the results obtained with the couple IAM-4-VP are presented in Table 1.

The bands 1 from the SDS-total, EtOH and SDS-soluble extracts were analyzed and found to include a common protein identified as a LMW-GS type-i (accession number Q9FEQ2). The $\mathrm{C}^{\mathrm{d}}$ and the $\mathrm{C}^{\mathrm{e}}$ were recovered carried by two distinct peptides and found oxidized, since only Cys-PE was detected. The peptide QCCQQLR comprising the side by side $\mathrm{C}^{\mathrm{f} 1}$ and $\mathrm{C}^{\mathrm{f} 2}$ was detected as carrying either two Cys-PE residues or one Cys-CAM together with one Cys-PE. Further MS/MS analysis allowed identifying only the $\mathrm{C}^{\mathrm{f} 2}$ as Cys-CAM. These results indicated that the $\mathrm{C}^{\mathrm{f} 2}$ co-exists in both reduced and engaged forms.

In the total protein extracts, an additional LMW-GS type-i (accession number Q19MN3) was identified from band 1. Very similar to the Q9FEQ2, it presents two substitutions at positions 276 and 344, an insertion at 296 and a deletion of 17 residues at 369. These alterations resulted in a shift by one amino-acid of the typical $C^{x^{*}}$ (from Cys-313 to Cys-314) and $C^{y}$ (from Cys-363 to Cys-364) and also modified the amino-acids in their immediate vicinity. Overall, on the five Cys identified, three occur exclusively in engaged form $\left(C^{d}, C^{e}\right.$ and $\left.C^{f 1}\right)$ whereas $C^{\mathrm{f} 2}$ and $\mathrm{C}^{\mathrm{y}}$ were found in both reduced and engaged forms

The analysis of bands 2, present in all sequential and total extracts, revealed a LMW-GS type$\mathrm{s}$ as the primary protein (accession number B2Y2R4). Overall, five Cys carried by three peptides were identified. The $\mathrm{C}^{\mathrm{d}}$ was found in reduced and oxidized form. This $\mathrm{C}^{\mathrm{d}}$ residue (Cys-243) coincided to the Cys-229 of LMW-GS band 1 (Q9FEQ2), since both sequences 
(B2Y2R4 and Q9FEQ2) differed only by a few mutations, including a Cys-Ser (SLAR vs CLAR) substitution. The peptide carrying the $\mathrm{C}^{\mathrm{e}}, \mathrm{C}^{\mathrm{f} 1}$ and $\mathrm{C}^{\mathrm{f} 2}$ residues was always identified as oxidized (3 Cys-PE, $3587.80 \mathrm{Da}$ ). The status of $\mathrm{C}^{\mathrm{y}}$ was variable according to the extract. In Tris- $\mathrm{HCl}$ or total extracts, this $\mathrm{C}^{\mathrm{y}}$ residue was recovered either in reduced (Cys-CAM) or oxidized form (Cys-PE) (Figure 4) whilst only Cys-PE was identified from EtOH and SDSsoluble sequential extracts.

The bands 3 evidenced in the $\mathrm{EtOH}$ and SDS-soluble sequential extracts were identified as a $\gamma$-gliadin (accession number B8XU43). Only two Cys, $C^{y}$ and $C^{\mathrm{z}}$ assumed to be involved in distinct intra-chain bonds $\left(\mathrm{C}^{\mathrm{w}}-\mathrm{C}^{\mathrm{Z}} \mathrm{C}^{\mathrm{f} 2}-\mathrm{C}^{\mathrm{y}}\right)$ were recovered as Cys-PE from the peptide TLPNMCNVYVRTDCSTSTHHLPA that missed the expected $\mathrm{R}$ or $\mathrm{K}$ final residue (missed cleavage) and carried an oxidized methionine residue. This result is consistent with our previous results, showing that this band was not labelled by a SH specific fluorescent probe (ATTO-Maleimide) (Ferreira et al. 2009). In consequence it was assumed that all the cysteine residues of this protein are involved in intra-chain disulfide bonds.

From bands 4, present in all sequential extracts a new LMW-GS type-m was identified (accession number A2TN61). From the Tris- $\mathrm{HCl}$ extract, six Cys were identified on four peptides. As already found for the LMW-GS type-s (band 2), the $\mathrm{C}^{\mathrm{d}}$ residue (Cys-116) was found in both reduced and oxidized forms (Fig. 5). The peptide including the $C^{\mathrm{e}}, \mathrm{C}^{\mathrm{f} 1}$ and $\mathrm{C}^{\mathrm{f} 2}$ residues (Cys-136, Cys-143 and Cys-144) gave two different peaks, one presenting two cysteine in oxidized form (1 Cys-CAM and 2 Cys-PE, 2449.010 Da) and another with the three (3 Cys-PE, 2498.081 Da). However, it was not possible to confirm by MS/MS which residue presented this double character. The $C^{f 1}-C^{c}$ intra-chain bond has been identified as primordial for the correct assembly of glutenin polymers (Lombardi et al., 2009), so it is likely that these both Cys could not be found other than oxidized. That leaves $C^{\mathrm{f} 2}$ or $\mathrm{C}^{\mathrm{e}}$ as 
candidate for the double labelling. For both A2TN61 and B2Y2R4, $C^{\mathrm{e}}$ and $\mathrm{C}^{\mathrm{d}}$ are flanked by the same amino-acid sequences. For the LMW-GS s-type (B2Y2R4) $\mathrm{C}^{\mathrm{e}}$ was found strictly oxidized. Both types are believed to be very similar (Huang \& Cloutier, 2008; Masci et al., 1998). For these reasons, we conjectured that $C^{\mathrm{f} 2}$ residue should be the one carrying the double labelling. Finally, the $\mathrm{C}^{\mathrm{y}}$ residue (Cys-253) was identified only in oxidized form, while the $C^{x^{*}}$ (Cys-205) was detected by linear mode and only within its reduced form (Fig.5).

In EtOH and SDS-soluble extracts, the A2TN61 was identified unambiguously due to the recovery of the specific peptide carrying the $C^{d}$ cysteine residue (Cys-116) in both its reduced and oxidized forms, whereas $\mathrm{C}^{\mathrm{y}}$ was recovered only in its oxidized form in opposite to what found in Tris- $\mathrm{HCl}$ extract.

In summary, five LMW-GS sequences and one $\gamma$-gliadin were identified from the analyzed LMW-GS bands. Equivalent results were obtained irrespective of the grain development time, however the redox state of similar Cys were different according to the LMW-GS considered but also according to the solvent used (Fig. 6).

Analysis of glutenin oligomers (Mr 200, 110 and $85 \mathrm{kDa}$ )

Irrespective of the grain development and for both SDS-soluble and total extracts, MALDITOF/TOF analysis of bands $a$ (about 200,000 $M_{\mathrm{r}}$ ) revealed the joint presence of the $1 \mathrm{Bx}$ and 1By HMW-GS 20 and of one LMW-GS type-s. Each of the two Cys of 1Bx HMW-GS 20 (accession number Q8RVX0) were identified both in reduced and oxidized forms (Table 1). In place of the expected HMW-GS 1By20 which is not registered in UniProt, a HMW-GS 1By15 was identified ( $M r 77334$, accession number B8PSA6) based on the presence of five peptides carrying six from the seven typical Cys of y-type HMW-GS $\left(C^{\mathrm{a}}, C^{\mathrm{b}}, \mathrm{C}^{1}, \mathrm{C}^{2}, \mathrm{C}^{\mathrm{d}}, \mathrm{C}^{\mathrm{z}}\right)$. Among these identified peptides, only the one carrying the $\mathrm{C}^{\mathrm{z}}$ cysteine residue was identified in a reduced form. The LMW-GS involved in this oligomer was the LMW-GS band 2 
(accession number B2Y2R4). Its $\mathrm{C}^{\mathrm{d}}$ (Cys-243) residue showed the same double reduced or oxidized labeling, as previously found for the free subunits. Based on its apparent molecular weight this oligomer was likely to include two HMW-GS and one LMW-GS s-type (Fig. 7).

The analysis of band $b$ migrating at $110 \mathrm{kDa}$ also indicated the presence of peptides from the 1Bx and 1By HMW-GS 20 and the B2Y2R4 LMW-GS. As for the oligomer band $a$, the $\mathrm{C}^{\mathrm{d}}$ residue of the LMW-GS and the two cysteines $\left(\mathrm{C}^{\mathrm{d}}, \mathrm{C}^{\mathrm{z}}\right)$ of the $1 \mathrm{Bx} 20$ were detected both as reduced (Cys-CAM) and oxidized (Cys-PE). The analysis of band $c$ from EtOH extracts present at $470^{\circ} \mathrm{Cd}$, revealed the presence of a mixture of peptides typical of the LMW-GS found as free subunits in the same extract (Q9FEQ2 and B2Y2R4). Consistently with the result obtained for the corresponding free LMW-GS, the $\mathrm{C}^{\mathrm{d}}$ residue from the B2Y2R4 was found in both reduced and oxidized forms. The others identified $\mathrm{Cys}, \mathrm{C}^{\mathrm{f} 1}$ and $\mathrm{C}^{\mathrm{f} 2}$ from the LMW-GS i-type (Q9FEQ2) were both found in their oxidized form as was the $\mathrm{C}^{\mathrm{y}}$ carried by a peptide coming from the B2Y2R4. It is interesting to note that none HMW-GS was identified in this oligomer.

\section{Discussion}

\subsection{Effectiveness of the approach}

Due to the few number of proteolytic cleavage sites (lysine and arginine) within the repetitive region, the first $C^{c}$ or the first two $C^{c} C^{b^{*}}$ residues from LMW-GS i- and s- or m-type, respectively, were intended to be included in large peptides $\left(>20,000 M_{\mathrm{r}}\right)$. The same can be projected to the $\mathrm{C}^{\mathrm{x}^{*}}$ from the LMW-GS m-type (>8000 $M_{\mathrm{r}}$ ). In opposite, the other cysteinecontaining peptides were typically within the $m / z, 800-3500$ range. Further tests in the linear mode did not allow to recover the large peptides apart from the 5422 Da peptide carrying the $\mathrm{C}^{\mathrm{x} *}$ of the LMW-GS band 4. The relatively low number of LMW-GS sequences of durum wheat in databanks, associated with the protein mixture obtained by electrophoresis 1-D, 
prevented, in some cases, the identification by PMF with a significant score. In addition, the MS/MS confirmation of all sequences of identified peptides has not been possible, especially for the low-mass peptides ( $<1000 \mathrm{Da})$. These peaks presented a low resolution, the isolation of the ion parent has been difficult and therefore the fragmentation was not conclusive.

Nevertheless, the number of recovered peptide sequences was enough to assign the selected protein bands to specific LMW-GS types. Band 1 and 2 which were markedly present in the total protein extract were assigned to i-type and s-type of LMW-GS subunits. Band 4, which can only be clearly evidenced in the sequential extracts, belongs to the m-type group of LMW-GS. These results are fully consistent with the proteomic analysis of $T$. durum LMWGS polypeptides fractionated on 2D gels showing that the main typical LMW-GS within the range of 35,000-45,000 $M_{\mathrm{r}}$ belongs to i- and s-type (Muccilli et al., 2010).

It is interesting to note that in some cases the retrieved peptides matched with protein sequences from T. monococcum or T. aestivum databases rather than from T.durum. As stated above the $T$. durum protein sequence database is far from completed while the different wheat species show high genome homology, because of their shared polyploidy. In addition silico search of GS sequences listed in the UniProt database, showed that cysteine containing peptides generally belongs to conserved domains. As consequence different GS even from different wheat species often present the same tryptic peptides patterns.

\subsection{Redox state of cysteine of glutenin subunits from immature durum wheat grains}

Primary sequences of LMW-GS m- and s-types share large similarities (Fig. 6). In their mature form, both present a conserved N-terminal sequence followed by a repetitive domain including the first residue $\left(\mathrm{C}^{\mathrm{c}}\right)$. Length of the repetitive domain varies according to the deletion or insertion of repeated units. The C-terminal is subdivided in three domains and includes the 7 other Cys. LMW-GS i-type lacks of N-terminal domain and all the 8 Cys are 
positioned within the C-terminal domain. The first and seventh $\mathrm{Cys}\left(\mathrm{C}^{\mathrm{b} *}, \mathrm{C}^{\mathrm{x} *}\right)$ of $\mathrm{m}-$ and stype LMW-GS are assumed to be involved in inter-chain bonds, while for i-type it concerns the third and seventh $\left(\mathrm{C}^{*}, \mathrm{C}^{\mathrm{x}}\right)$. All other Cys would form intra-chain bonds (D'Ovidio \& Masci, 2004; Keck et al., 1995; Köhler et al., 1993; Müller et al., 1998).

The general structure of m-, s- and i-LMW-GS is presented in figure 6, the Cys were marked in red, green or grey when detected as Cys-PE, Cys-CAM or not recovered. Contrary to expectations, some Cys assumed to be involved in intra-chain bonds were detected jointly alkylated by the first and the second alkylating agent (typically $\mathrm{C}^{\mathrm{d}}, \mathrm{C}^{\mathrm{f} 2}$ and $\mathrm{C}^{\mathrm{y}}$ ). This result demonstrates unambiguously that in the newly synthesised LMW-GS, Cys otherwise known as part of intra-chain bonds are in reduced form. Therefore, the oxidative folding of LMW-GS appears to be a late process uncompleted at this stage of grain development. This assumption is fully supported by the simultaneous double labelling of $\mathrm{C}^{\mathrm{f} 2}$ and $\mathrm{C}^{\mathrm{y}}$ from i-LMW-GS recovered in the SDS-total extract (Q19MN3).

Actually, according to Lombardi et al. (2009), only the $C^{\mathrm{c}}-\mathrm{C}^{\mathrm{f} 1}$ intra-chain bond would play a pivotal role for the correct assembly of glutenin polymers. Concomitant substitution of the $\mathrm{C}^{\mathrm{c}}$ and $\mathrm{C}^{\mathrm{f} 1}$ by serine would lead to improper LMW-GS folding and to inappropriate disulfide bonds formation. On the other hand, removal of any other intra-chain disulfide bonds $\left(C^{d} / C^{e}\right.$ or $\mathrm{C}^{\mathrm{f} 2} / \mathrm{C}^{\mathrm{y}}$ ) had no significant effects, which suggests that they have a limited role in the stabilization of the local structure (Lombardi et al., 2009). Despite of the lack of recovery of $C^{c}$ carrying peptides, we found no indication that $C^{c}-C^{f 1}$ intra-chain could be opened, since $C^{f 1}$ was always identified as a Cys-PE. Furthermore, we found that the $\mathrm{C}^{\mathrm{d}}$ residue of s-LMW-GS recovered in oligomers bands could still carry alternative adducts. The oxidative folding of the less critical intra-chain bonds $\mathrm{C}^{\mathrm{d}} / \mathrm{C}^{\mathrm{e}}$ and perhaps also $\mathrm{C}^{\mathrm{f} 2} / \mathrm{C}^{\mathrm{y}}$ would not be required for the correct assembly of LMW-GS oligomers. In contrast to LMW-GS, HMW-GS 1By20 would 
rapidly achieve proper oxidative folding (Fig. 7). For this GS all Cys recovered were in CysPE form except $\mathrm{C}^{Z}$, which is assumed to be involved in GS inter-chain pairing (Shani et al., 1994; Shani et al., 1992).

A second point that deserves discussion concerns the asymmetric labelling of cysteine pairs belonging to the same intra-chain bonds. In many cases, partners of the same intra-chain bond $\left(C^{d}-C^{e}\right.$ and $\left.C^{\mathrm{f} 2}-C^{y}\right)$ adopted distinct redox states. A simple explanation would be an incomplete IAM alkylation because Cys were hidden or inaccessible. Nevertheless when IAM alkylation was performed under strong denaturant condition, in the presence of $2 \%$ SDS, asymmetric labelling of cysteine pairs was also observed. To exclude incomplete first alkylation, we investigated Cys-PAM presence. Indeed, free cysteines may be modified by traces of unpolymerized acrylamide in the gel, resulting in the formation of Cys-S- $\beta$ propionamide (Cys-PAM, 71 kDa) (Brune, 1992; Patterson, 1994; Sechi \& Chait, 1998). Careful examination of MALDI spectra did not reveal any Cys-PAM peptide.

Excluding incomplete PSH alkylation, a temporary glutathionylation of Cys can be envisaged. Indeed, we have recently shown that glutenin polymer accumulation coincided with the increase of protein glutationylation. We have also proposed glutathionylation as a protective mechanism against irreversible thiol oxidation and also as a required intermediate step for glutenin subunits pairing (Ferreira et al., 2012b). In this respect, $C^{\mathrm{e}}$ residue would be preferentially glutathionylated and so inaccessible to the first alkylant, differing to the $\mathrm{C}^{\mathrm{d}}$ its future disulfide pair. Glutathionylation would also concern the both Cys of HMW-GS 1Bx 20 which coexist in both reduced and oxidized forms.

\section{Concluding remarks}

One of the main challenges of cereal chemists is to understand the genesis and structure of glutenin polymers assembly, since it is the major determinant of the wheat unique rheological 
properties. In particular how grain developmental conditions (e.g. thermal or drought stresses) act to modify glutenin polymers assembly and their rheological properties remains an open question. This study raised interesting issues about the cysteine pairing of monomeric LMWGS and therefore on the dynamic of disulfide bonds formation. In particular, our results showed Cys marked by both alkylating agents, suggesting the existence of equilibrium between different redox states. These results raise new questions; it seems that the folding of LMW-GS and the establishment of their intra-chain disulfide bonds are late events, probably subsequent to their insertion in oligomeric assemblies. Taking into account the great similarity between LMW-GS and gliadins, which are rapidly folded after their synthesis, this result was not expected. The pending question remains the role of the thiols involved in intrachain bonds in the polymers assembly.

6. This study, conducted during developmental stages of grain, highlighted the significance of a dynamic approach to understand the mechanism of glutenin polymers assembly. Therefore, this approach can be used as a powerful tool for studies of wheat genetic variability and transgenic lines associated with grain quality improvement.Acknowledgements

This work was supported by the Fond Unique Interministériel (GARICC project, grant $\mathrm{n}^{\circ}$ 062-90-6310) through the Q@ liMéditerranée competitiveness cluster. Dr. Yves Popineau is acknowledged for the helpful comments on earlier version of the manuscript. The authors thank Stéphanie Deligny-Penninck and Gilbert Deshayes for excellent technical assistance.

\section{References}

Alvarez, S., Wilson, G. H., \& Chen, S. (2009). Determination of in vivo disulfide-bonded proteins in Arabidopsis. Journal of Chromatography B, 877 (1-2), 101-104.

Bloom, A. J., Smart, D. R., Nguyen, D. T., \& Searles, P. S. (2002). Nitrogen assimilation and growth of wheat under elevated carbon dioxide. Proceedings of the National Academy of Sciences of the United States of America, 99 (3), 1730-1735. 
Brune, D. C. (1992). Alkylation of cysteine with acrylamide for protein sequence analysis. Analytical Biochemistry, 207 (2), 285-290.

D'Ovidio, R., \& Masci, S. (2004). The low-molecular-weight glutenin subunits of wheat gluten. Journal of Cereal Science, 39, 321-339.

De Gara, L., de Pinto, M. C., Moliterni, V. M. C., \& D'Egidio, M. G. (2003). Redox regulation and storage processes during maturation in kernels of Triticum durum. Journal of Experimental Botany, 54 (381), 249-258.

Ferreira, M. S. L., Bonicel, J., Rosa, N. N., Samson, M. F., \& Morel, M. H. (2009). How are gluten polymers assembled during grain filling in durum wheat? In G. Branlard (Ed.), Gluten proteins 2009, Xth International Gluten Workshop (pp. 28-32). ClermontFerrand, France.

Ferreira, M. S. L., Martre, P., Mangavel, C., Girousse, C., Rosa, N. N., Samson, M. F., \& Morel, M. H. (2012a). Physicochemical control of durum wheat grain filling and glutenin polymer assembly under different temperature regimes. Journal of Cereal Science, 56 (1), 58-66.

Ferreira, M. S. L., Samson, M. F., Bonicel, J., \& Morel, M. H. (2012b). Relationship between endosperm cells redox homeostasis and glutenin polymers assembly in developing durum wheat grain. Plant Physiology and Biochemistry, 61, 36-45.

Foley, S. F., Sun, Y., Zheng, T. S., \& Wen, D. (2008). Picomole-level mapping of protein disulfides by mass spectrometry following partial reduction and alkylation. Analytical Biochemistry, 377 (1), 95-104.

Gao, L. Y., Ma, W. J., Chen, J., Wang, K., Li, J., Wang, S. L., Bekes, F., Appels, R., \& Yan, Y. M. (2010). Characterization and comparative analysis of wheat high molecular weight glutenin subunits by SDS-PAGE, RP-HPLC, HPCE, and MALDI-TOF-MS. Journal of Agricultural and Food Chemistry, 58 (5), 2777-2786.

Gobin, P., Ng, P. K. W., Buchanan, B. B., \& Kobrehel, K. (1997). Sulfhydryl-disulfide changes in proteins of developing wheat grain. Plant Physiology and Biochemistry, 35 (10), 777-783.

Huang, X.-Q., \& Cloutier, S. (2008). Molecular characterization and genomic organization of low molecular weight glutenin subunit genes at the Glu-3 loci in hexaploid wheat (Triticum aestivum L.). Theoretical and Applied Genetics, 116 (7), 953-966.

Keck, B., Kohler, P., \& Wieser, H. (1995). Disulfide bonds in wheat gluten - cystine peptides derived from gluten proteins following peptic and thermolytic digestion. Zeitschrift Fur Lebensmittel-Untersuchung Und-Forschung, 200 (6), 432-439.

Köhler, P., Belitz, H. D., \& Wieser, H. (1993). Disulfide bonds in wheat gluten - Further cystine peptides from high-molecular-weight (HMW) and low-molecular-weight (LMW) subunits of glutenin and from gamma-gliadins. Zeitschrift Fur LebensmittelUntersuchung Und-Forschung, 196 (3), 239-247.

Liu, L., Ikeda, T. M., Branlard, G., Pena, R. J., Rogers, W. J., Lerner, S. E., Kolman, M. A., Xia, X. C., Wang, L. H., Ma, W. J., Appels, R., Yoshida, H., Wang, A. L., Yan, Y. M., \& He, Z. H. (2010). Comparison of low molecular weight glutenin subunits identified by SDS-PAGE, 2-DE, MALDI-TOF-MS and PCR in common wheat. BMC Plant Biology, 10.

Lombardi, A., Barbante, A., Cristina, P. D., Rosiello, D., Castellazzi, C. L., Sbano, L., Masci, S., \& Ceriotti, A. (2009). A Relaxed specificity in interchain disulfide bond formation characterizes the assembly of a low-molecular-weight glutenin subunit in the endoplasmic reticulum. Plant Physiology, 149 (1), 412-423. 
Masci, S., D’Ovidio, R., Lafiandra, D., \& Kasarda, D. D. (1998). Characterization of a lowmolecular-weight glutenin subunit gene from bread wheat and the corresponding protein that represents a major subunit of the glutenin polymer. Plant Physiology, 118, 11471158.

Morel, M. H., Dehlon, P., Autran, J. C., Leygue, J. P., \& Bar-L'Helgouac'h, C. (2000). Effects of temperature, sonication time, and power settings on size distribution and extractability of total wheat flour proteins as determined by size-exclusion highperformance liquid chromatography. Cereal Chemistry, 77 (5), 685-691.

Muccilli, V., Cunsolo, V., Saletti, R., Foti, S., Margiotta, B., Scossa, F., Masci, S., \& Lafiandra, D. (2010). Characterisation of a specific class of typical low molecular weight glutenin subunits of durum wheat by a proteomic approach. Journal of Cereal Science, 51 (1), 134-139.

Müller, S., Vensel, W. H., Kasarda, D. D., Köhler, P., \& Wieser, H. (1998). Disulphide bonds of adjacent cysteine residues in low molecular weight subunits of wheat glutenin. Journal of Cereal Science, 27 (2), 109-116.

Naeem, H. A., \& MacRitchie, F. (2005). Polymerization of glutenin during grain development in near-isogenic wheat lines differing at Glu-D1 and Glu-B1 in greenhouse and field. Journal of Cereal Science, 41 (1), 7-12.

Patterson, S. D. (1994). From electrophoretically separated protein to identification: strategies for sequence and mass analysis. Analytical Biochemistry, 221 (1), 1-15.

Popineau, Y., Cornec, M., Lefebvre, J., \& Marchylo, B. (1994). Influence of high Mr glutenin subunits on glutenin polymers and rheological properties of glutens and gluten subfractions of near-isogenic lines of wheat Sicco. Journal of Cereal Science, 19 (3), 231-241.

Rhazi, L., Cazalis, R., \& Aussenac, T. (2003). Sulfhydryl-disulfide changes in storage proteins of developing wheat grain: influence on the SDS-unextractable glutenin polymer formation. Journal of Cereal Science, 38 (1), 3-13.

Rogers, L. K., Leinweber, B. L., \& Smith, C. V. (2006). Detection of reversible protein thiol modifications in tissues. Analytical Biochemistry, 358 (2), 171-184.

Schnaible, V., Wefing, S., Bucker, A., Wolf-Kummeth, S., \& Hoffmann, D. (2002). Partial reduction and two-step modification of proteins for identification of disulfide bonds. Analytical Chemistry, 74 (10), 2386-2393.

Sechi, S., \& Chait, B. T. (1998). Modification of cysteine residues by alkylation. A tool in peptide mapping and protein identification. Analytical Chemistry, 70 (24), 5150-5158.

Shani, N., Rosenberg, N., Kasarda, D. D., \& Galili, G. (1994). Mechanisms of assembly of wheat high molecular weight glutenins inferred from expression of wild-type and mutant subunits in transgenic tobacco. Journal of Biological Chemistry, 269 (12), 89248930.

Shani, N., Steffen-Campbell, J. D., Anderson, O. D., Greene, F. C., \& Galili, G. (1992). Role of the amino- and carboxy-terminal regions in the folding and oligomerization of wheat high molecular weight glutenin subunits. Plant Physiol., 98 (2), 433-441.

Shewry, P. R., Underwood, C., Wan, Y., Lovegrove, A., Bhandari, D., Toole, G., Mills, E. N. C., Denyer, K., \& Mitchell, R. A. C. (2009). Storage product synthesis and accumulation in developing grains of wheat. Journal of Cereal Science, 50 (1), 106-112.

Zhang, M., \& Kaltashov, I. A. (2006). Mapping of protein disulfide bonds using negative ion fragmentation with a broadband precursor selection. Analytical Chemistry, 78 (14), 4820-4829. 
Zhang, Q., Dong, Y., An, X., Wang, A., Zhang, Y., Li, X., Gao, L., Xia, X., He, Z., \& Yan, Y. (2008). Characterization of HMW glutenin subunits in common wheat and related species by matrix-assisted laser desorption/ionization time-of-flight mass spectrometry (MALDI-TOF-MS). Journal of Cereal Science, 47 (2), 252-261. 
Table Caption

Table 1. Protein identification by MALDI-TOF analysis and MS/MS confirmation of cysteine containing peptides.

Figure Captions

Figure 1. Main steps of the differential alkylation used to investigate the redox state of cysteine residues by MALDI-TOF/TOF analysis.

Figure 2. SDS-PAGE profiles under non-reducing (A) and reducing (B) conditions of sequential protein extracts alkylated by using N-ethyl-maleimide (N) and Iodoacetamide (I). Identified bands migrating at 200 (a), 110 (b), 85 (c) and 30-45 $\mathrm{kDa}(1,2,3,4)$ were analysed by MALDI-TOF.

Figure 3. SDS-PAGE profile of total protein extracts alkylated by N-ethyl-maleimide $(\mathrm{N})$ and Iodoacetamide (I). Identified bands migrating at 200, 110 and $45 \mathrm{kDa}$ (LMW-GS 1, 2) were analysed by MALDI-TOF.

Figure 4. Details of the spectrum of the Tris-HCl soluble LMW-GS 2 firstly alkylated by Iodoacetamide (Cys-CAM) and after reduction by 4-Vinyl-pyridiethyl (Cys-PE). Arrows indicate Cys peptides. *methionine residue oxidized.

Figure 5. Details of the spectrum of the Tris-HCl soluble LMW-GS 4 firstly alkylated by Iodoacetamide (Cys-CAM) and after reduction by 4-Vinyl-pyridiethyl (Cys-PE). Arrows indicate Cys peptides. *methionine residue oxidized.

Figure 6. Schema of the LMW-GS structures and the Cys redox state identified by MALDITOF/TOF. Cys are designed according to the letter system porposed by Köhler et al., (1993). Codes on the left correspond to the protein accession numbers in Expasy. In green, reduced Cys, in red, oxidized Cys and in grey, no identified Cys.

Figure 7. Composition of glutenin oligomers migrating at $200 \mathrm{kDa}$. In green, reduced Cys, in red, oxidized Cys and in grey, no identified Cys. 


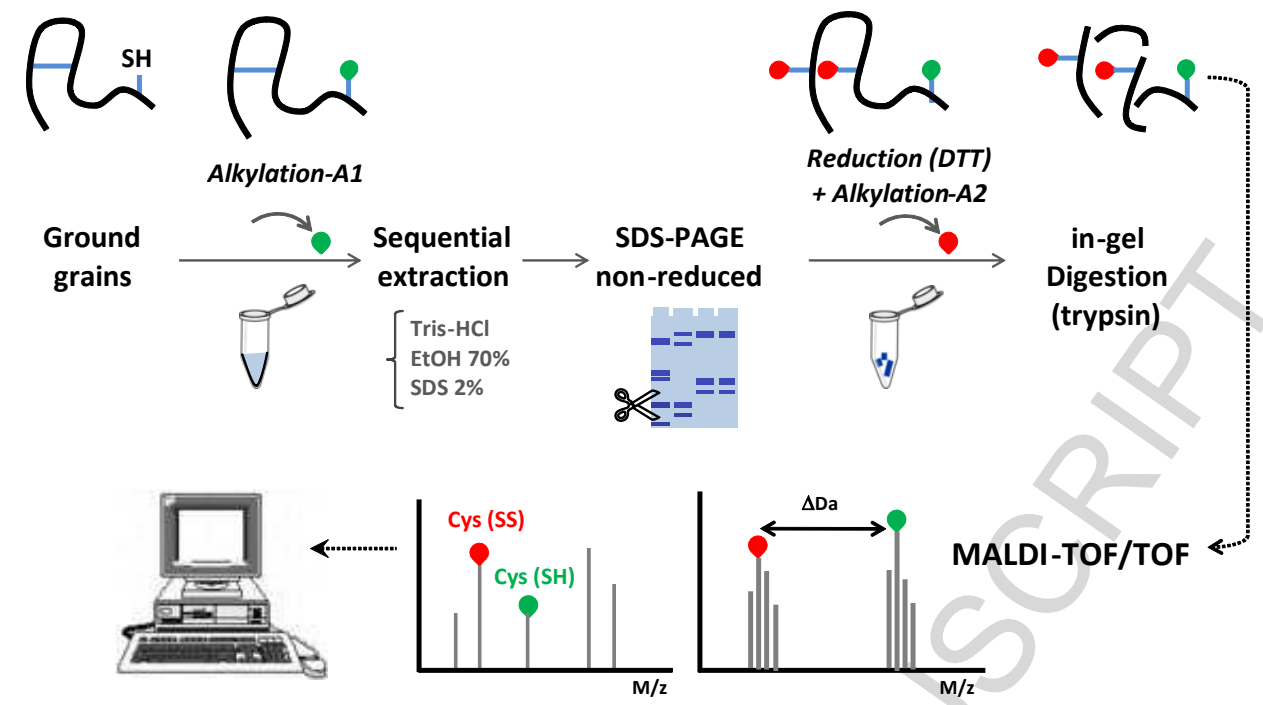

Figure 1. 


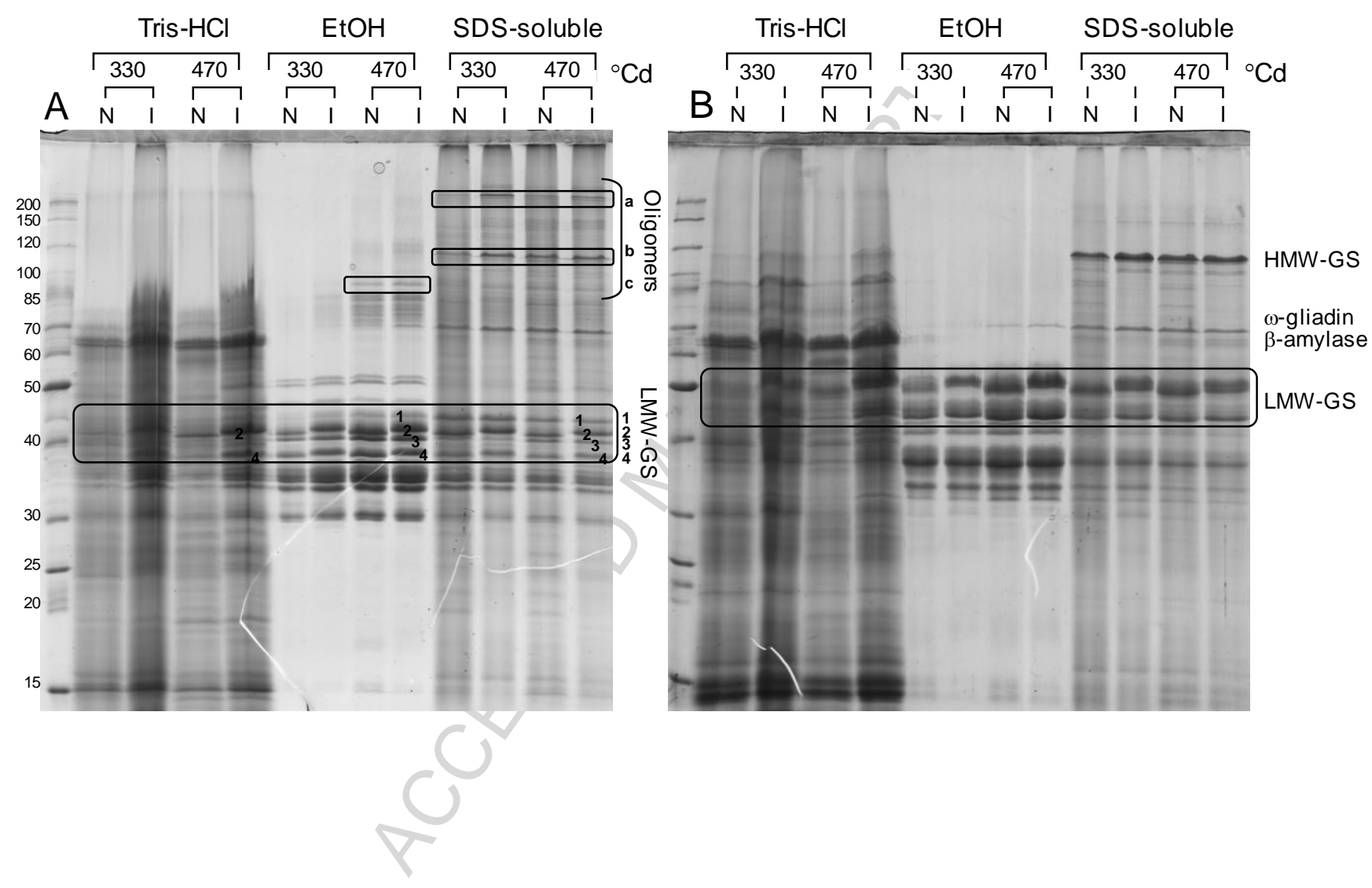


Figure 3.

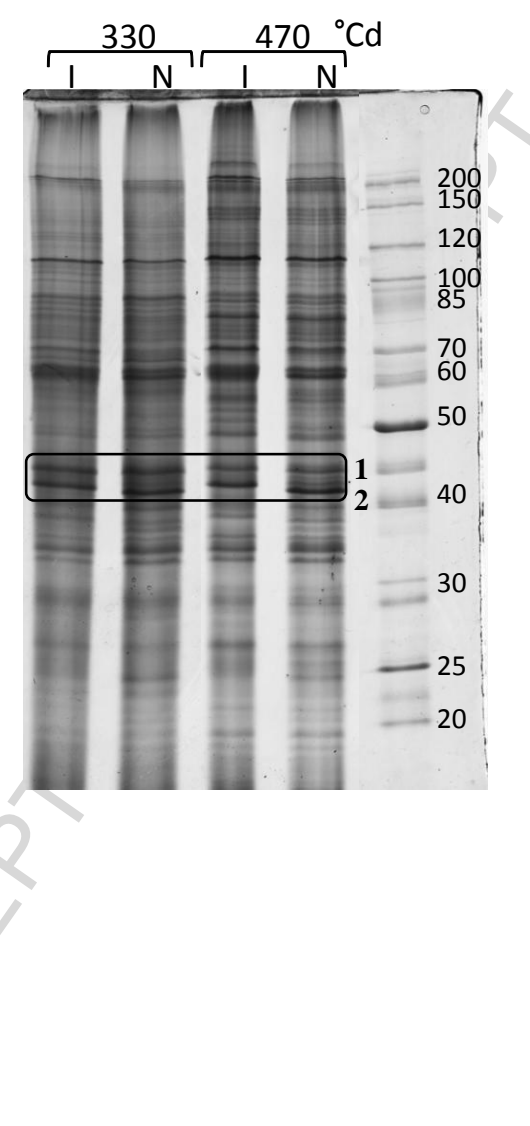



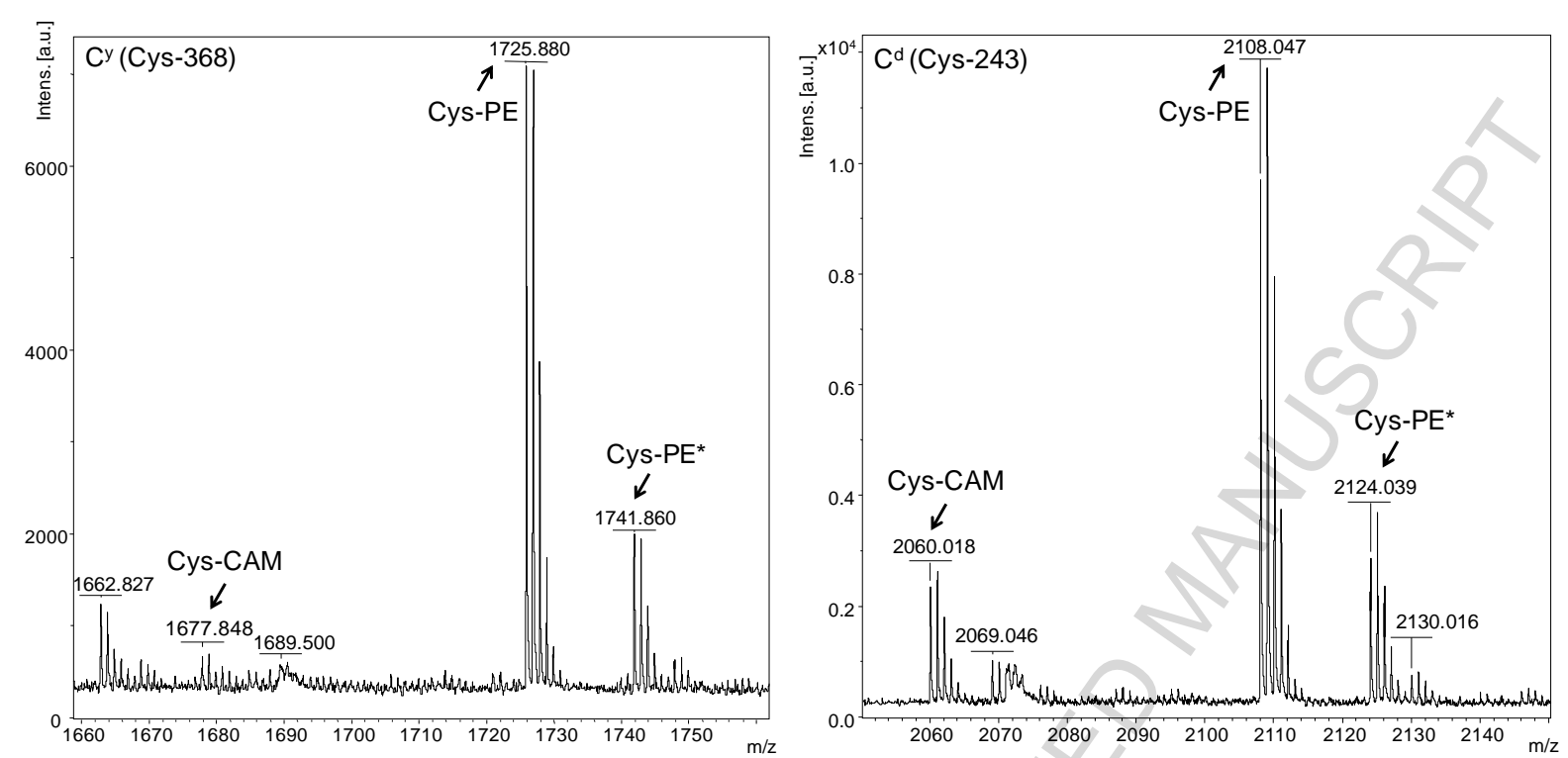

Figure 4. 

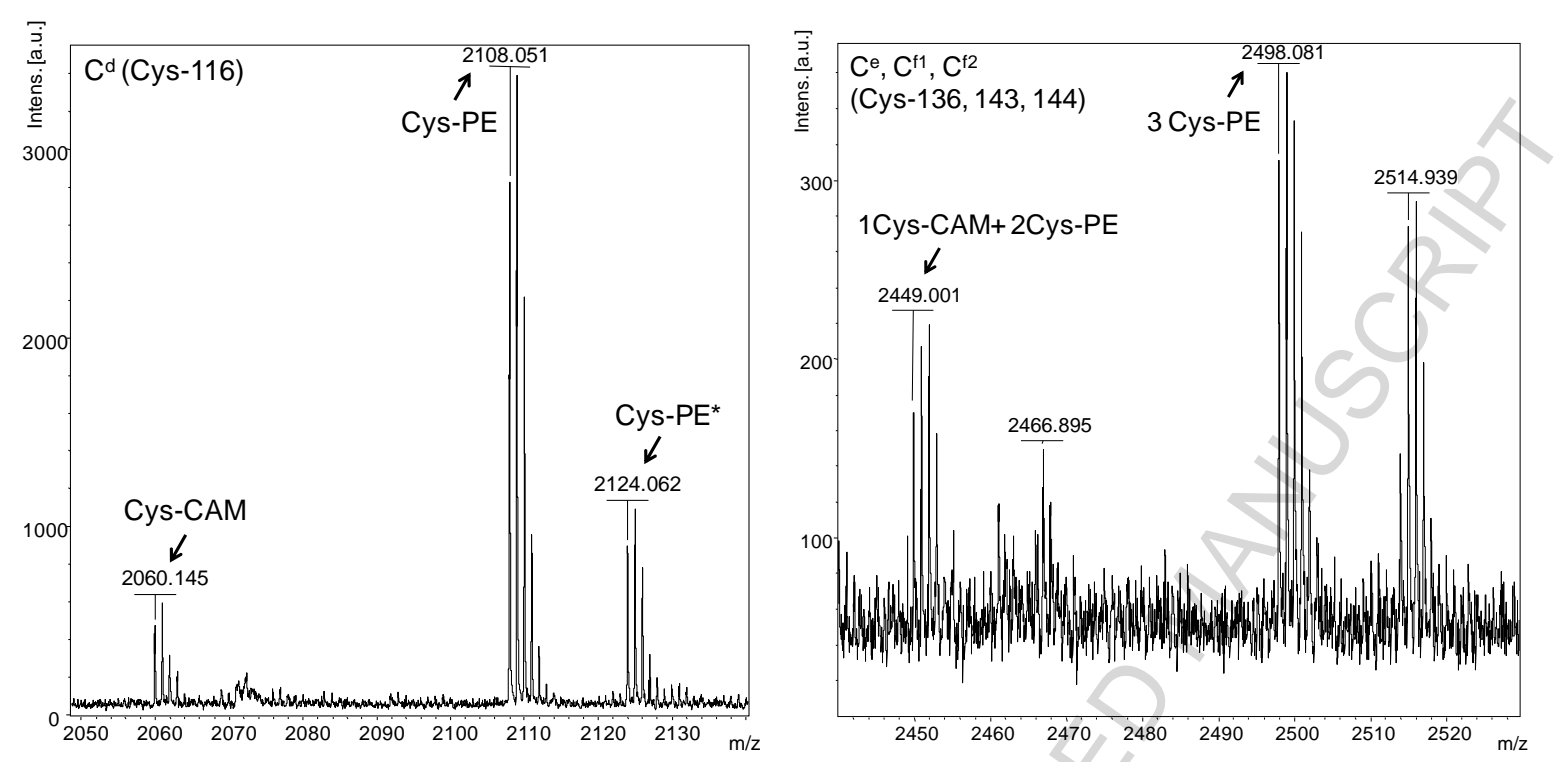

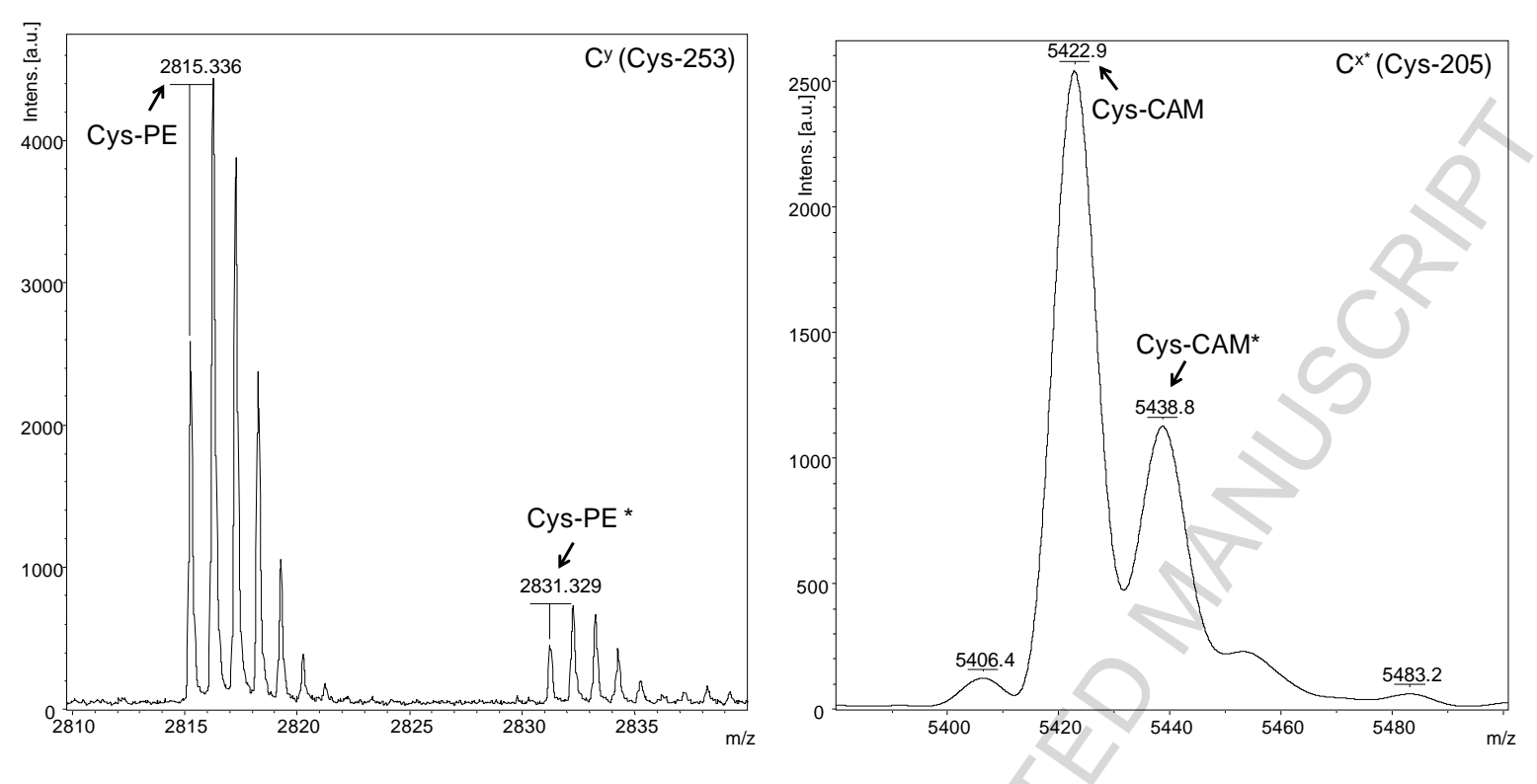

Figure 5 

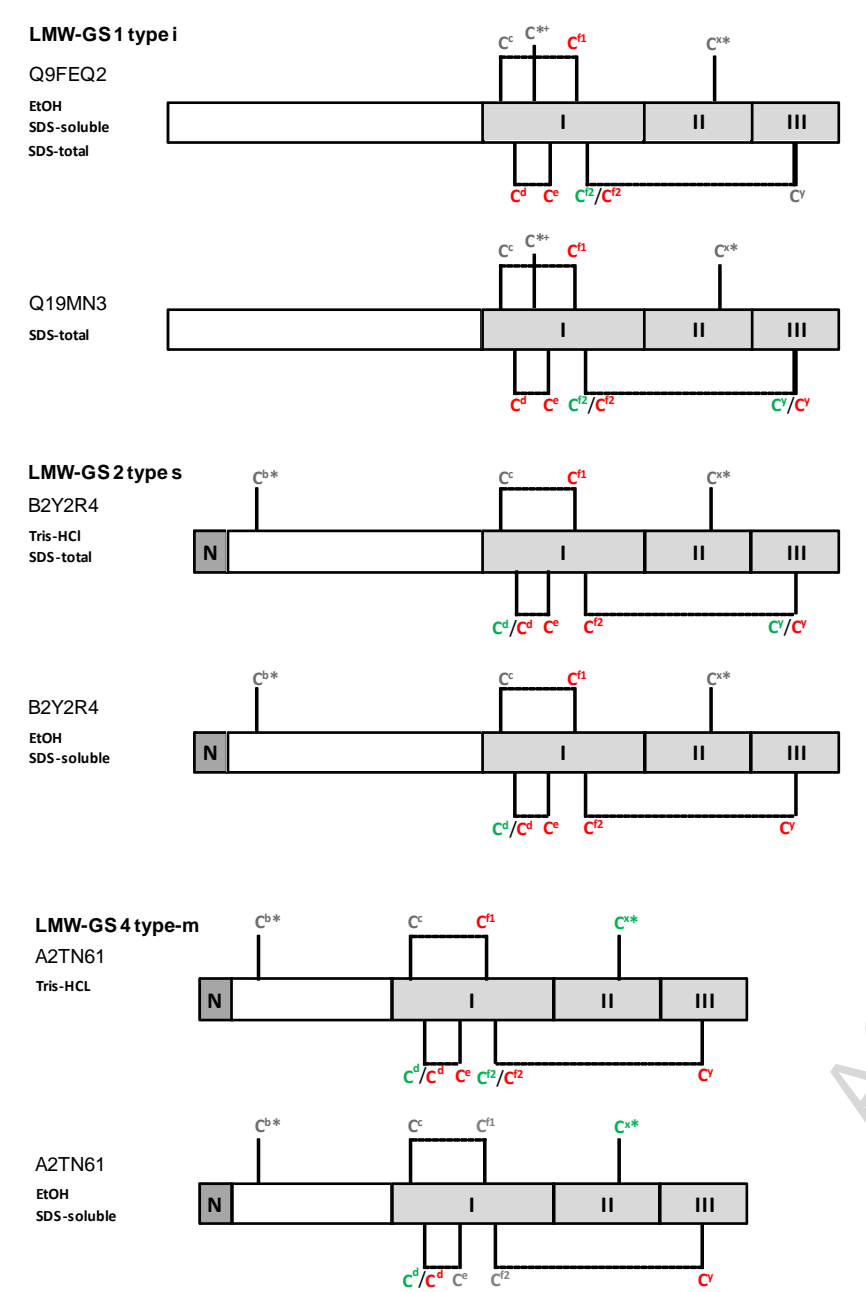

Figure 6. 

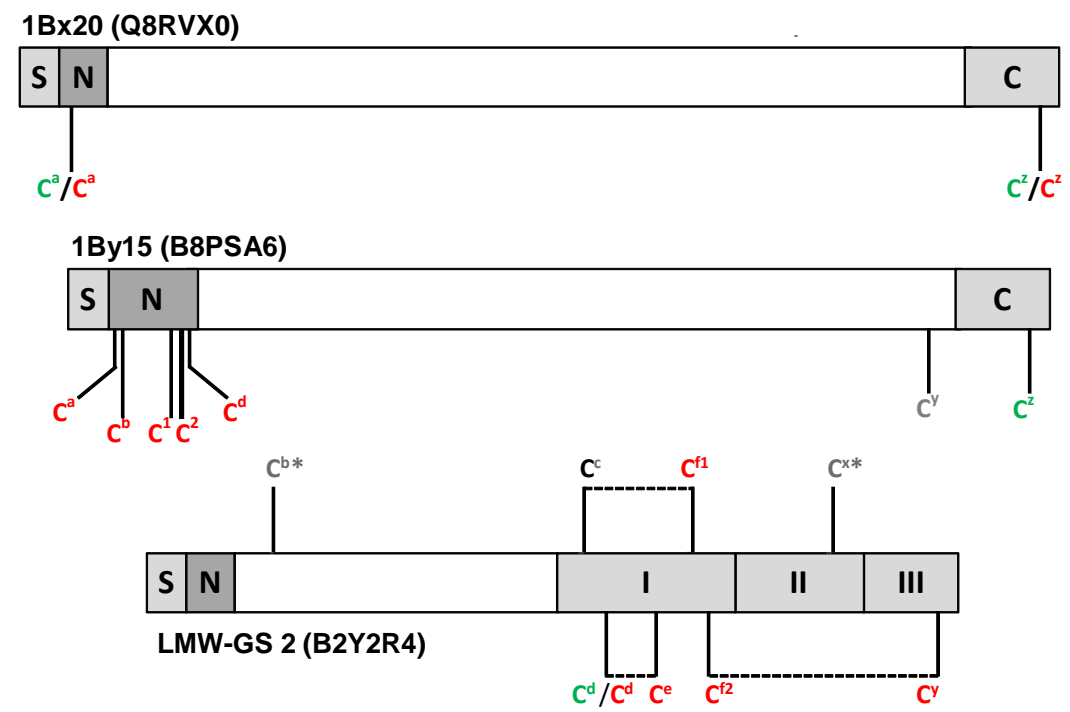

Figure 7. 
Table 1. Protein identification by MALDI-TOF analysis and MS/MS confirmation of cysteine containing peptides.

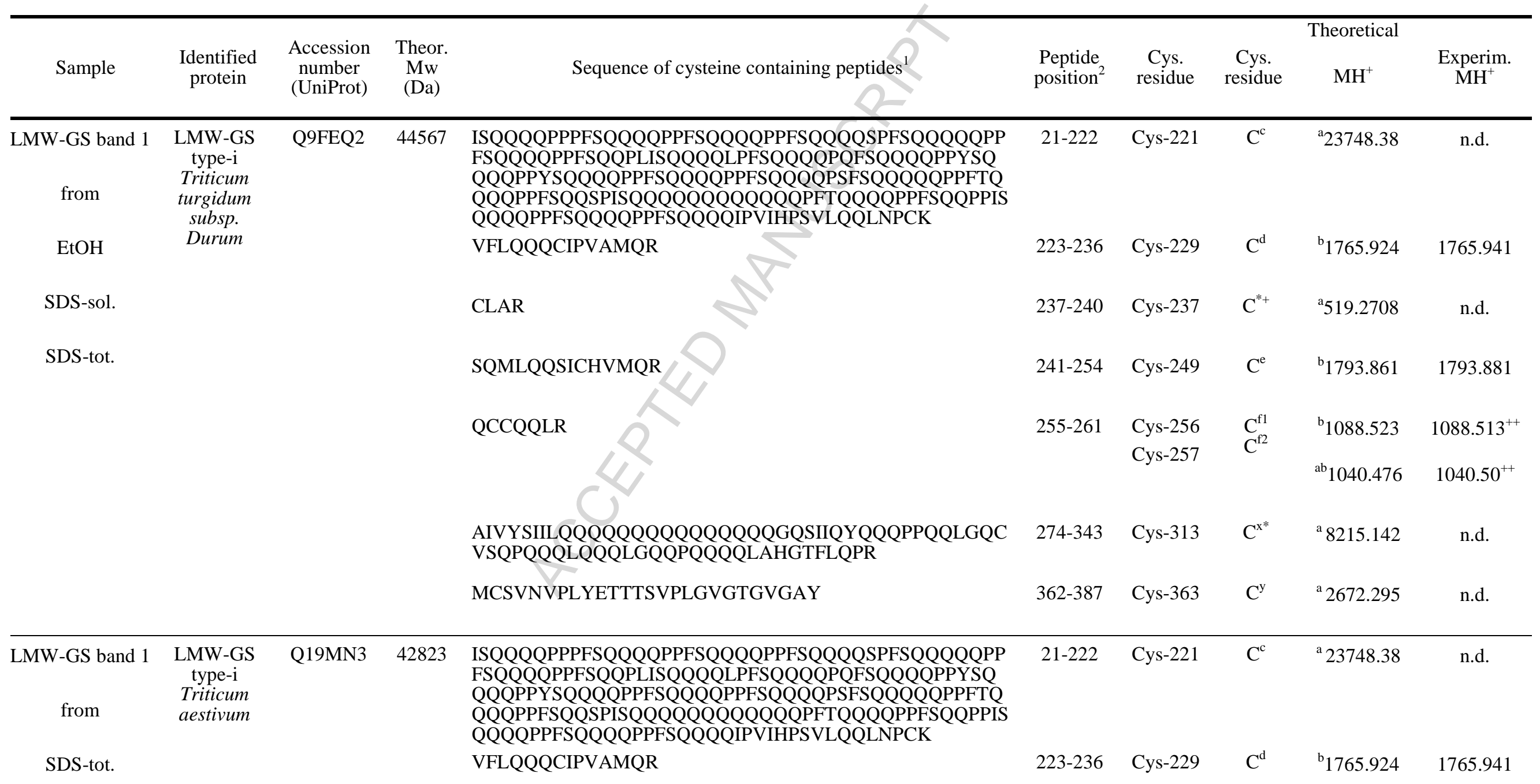


CLAR

SQMLQQSICHVMQR

QCCQQLR

AIIYSIILQQQQQQQQQQQQQQQGQSIIQYQQQPPQQLGQC

VSQPQQQLQQQLGQQPQQQQLAHGTFLQPHQIAQLEVMTS

IALR

MCSVNVP

$\begin{array}{ccccc}237-240 & \text { Cys-237 } & \text { C }^{*+} & { }^{a} 519.2708 & \text { n.d. } \\ 241-254 & \text { Cys-249 } & C^{\mathrm{e}} & { }^{\mathrm{b}} 1793.861 & 1793.881 \\ & & & & \\ 255-261 & \text { Cys-256 } & \mathrm{C}^{\mathrm{f} 1} & { }^{\mathrm{b}} 1088.523 & 1088.513^{++} \\ & \text {Cys-257 } & \mathrm{C}^{\mathrm{f} 2} & { }^{\mathrm{ab}} 1040.476 & 1040.50^{++} \\ & & & & \\ 274-358 & \text { Cys-314 } & \mathrm{C}^{\mathrm{x}^{*}} & { }^{\mathrm{a}} 9892.034 & \text { n.d. } \\ & & & & \\ 363-369 & \text { Cys-364 } & \mathrm{C}^{\mathrm{y}} & { }^{\mathrm{a}} 806.354 & 806.3017 \\ & & & { }^{\mathrm{b}} 854.390 & 854.317\end{array}$

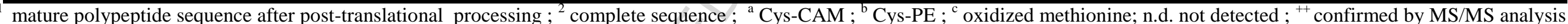


Table 1 (continuation). Protein identification by MALDI-TOF analysis and MS/MS confirmation of cysteine containing peptides.

\begin{tabular}{|c|c|c|c|c|c|c|c|c|c|}
\hline & & & & & & & & Theoretical & \\
\hline Sample & $\begin{array}{l}\text { Identified } \\
\text { protein }\end{array}$ & $\begin{array}{c}\text { Accession } \\
\text { number } \\
\text { (UniProt) }\end{array}$ & $\begin{array}{l}\text { Theor. } \\
\text { Mw } \\
\text { (Da) }\end{array}$ & Sequence of cysteine containing peptides & $\begin{array}{l}\text { Peptide } \\
\text { position }\end{array}$ & $\begin{array}{l}\text { Cysteine } \\
\text { residue }\end{array}$ & $\begin{array}{l}\text { Cys. } \\
\text { residue }\end{array}$ & $\mathrm{MH}^{+}$ & $\begin{array}{l}\text { Experim. } \\
\mathrm{MH}^{+}\end{array}$ \\
\hline LMW-GS band 2 & LMW-GS & B2Y2R4 & 44540 & SHIPGLERPSQQQPLPPQQTLSHHHQQQPIQQQPHQFPQQQP & $21-236$ & Cys-66 & $\mathrm{C}^{\mathrm{b}^{*}}$ & ${ }^{\mathrm{a}} 24756.396$ & n.d. \\
\hline & $\begin{array}{l}\text { type-s } \\
\text { Triticum }\end{array}$ & & & 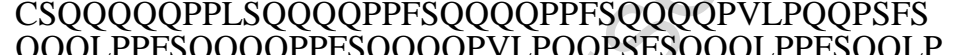 & & Cys-235 & $\mathrm{C}^{\mathrm{c}}$ & & \\
\hline from & aestivum & & & PFSQQQQPVLPQQPPFSQQQLPPFSQQLPPFSQQQQPVLPQQ & & & & & \\
\hline Tric_HCl & & & & $\begin{array}{l}\text { PPFSQQQQQQILPQQPPFSQQQHPVLLQQQIPFVHPSILQQL } \\
\text { NPCK }\end{array}$ & & & & & \\
\hline 1110-11C & & & & VFLQQQCSPVAMQSLAR & $237-254$ & Cys-243 & $\mathrm{C}^{\mathrm{d}}$ & ${ }^{\mathrm{a}} 2060.042$ & $2060.059^{++}$ \\
\hline EtOH & & & & & & & & $\mathrm{b}_{2} 2108.078$ & $2108.184^{++}$ \\
\hline SDS-sol. & & & & SQMLQQSSCHVMQQQC & $255-282$ & Cys-263 & $\mathrm{C}^{\mathrm{e}}$ & ${ }^{b} 3587.659$ & 3587.80 \\
\hline SDS-tot. & & & & & & Cys-270 & $\mathrm{C}_{\mathrm{f} 2}^{\mathrm{f} 1}$ & & \\
\hline & & & & & & Cys-271 & & & \\
\hline & & & & $\begin{array}{l}\text { AIVYSIILQEQQQVQGSIQTQQQQPQQLGQCVSQPQQQSQQ } \\
\text { QLGQQPQQQQLAQGTFLQP HQIAQLEVMTSIALR }\end{array}$ & $288-362$ & Cys-318 & $C^{x^{*}}$ & a8518.338 & n.d. \\
\hline & & & & TLPTMCNVNVPLYR & $363-376$ & Cys-368 & $\mathrm{C}^{\mathrm{y}}$ & a 1677.845 & $1677.855^{++}$ \\
\hline & & & & & & & & ${ }^{\mathrm{b}} 1725.882$ & $1725.969^{++}$ \\
\hline LMW-GS band 3 & $\begin{array}{l}\gamma \text {-gliadin } \\
\text { Triticum }\end{array}$ & B8XU43 & 31953 & $\begin{array}{l}\text { IQVDPSGQVQWPQQQPFPQPQPFSQQPQQAFPQPQQTFPLQ } \\
\text { PHOVFPOPOOPOOOFPOPOOPOOPFPOPOOPOLPFPOPFPO }\end{array}$ & $21-158$ & Cys-157 & $\mathrm{C}^{\mathrm{c}}$ & ${ }^{\mathrm{b}} 15990.60$ & n.d. \\
\hline from & monococc. & & & $\begin{array}{l}\text { PQQPQQPFPQSQQPQQPFL QPQQQFPQPQPQQSSPQQQ } \\
\text { QPLIQPYLQQQMNPCK }\end{array}$ & & & & & \\
\hline $\mathrm{EtOH}$ & & & & NYLLQQCNPVSLVSSLVSMILPR & $159-181$ & Cys-165 & $\mathrm{C}^{\mathrm{d}}$ & b2679.436 & n.d. \\
\hline
\end{tabular}


SDS-sol. SDCQVMQQQCCQQLAQIPR

QLQCTAIHSVVHAIIMQQEQQGIQILRPLFQLVQGQGIIQPQ QPAQYEVIR

TLPNMCNVYVRTDCSTSTHHLPA (miss cleavage)

\begin{tabular}{lllll} 
182-200 & Cys-184 & C $^{\mathrm{e}}$ & ${ }^{\mathrm{b}} 2522.156$ & n.d. \\
& Cys-191 & $\mathrm{C}^{\mathrm{f} 1}$ & & \\
& Cys-192 & $\mathrm{C}^{\mathrm{f} 2}$ & & \\
$201-251$ & Cys-204 & $\mathrm{C}^{\mathrm{w}}$ & ${ }^{\mathrm{b}} 5922.179$ & n.d. \\
& & & & \\
$257-279$ & Cys-262 & $\mathrm{C}^{\mathrm{y}}$ & ${ }^{\mathrm{b}} 2770.290$ & ${ }^{\mathrm{c}} 2786.35$ \\
& Cys-270 & $\mathrm{C}^{\mathrm{z}}$ & & \\
\hline
\end{tabular}

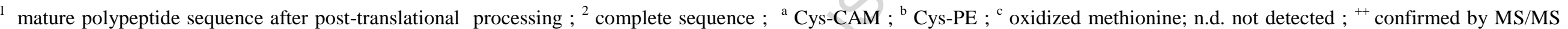


Table 1 (continuation). Protein identification by MALDI-TOF analysis and MS/MS confirmation of cysteine containing peptides.

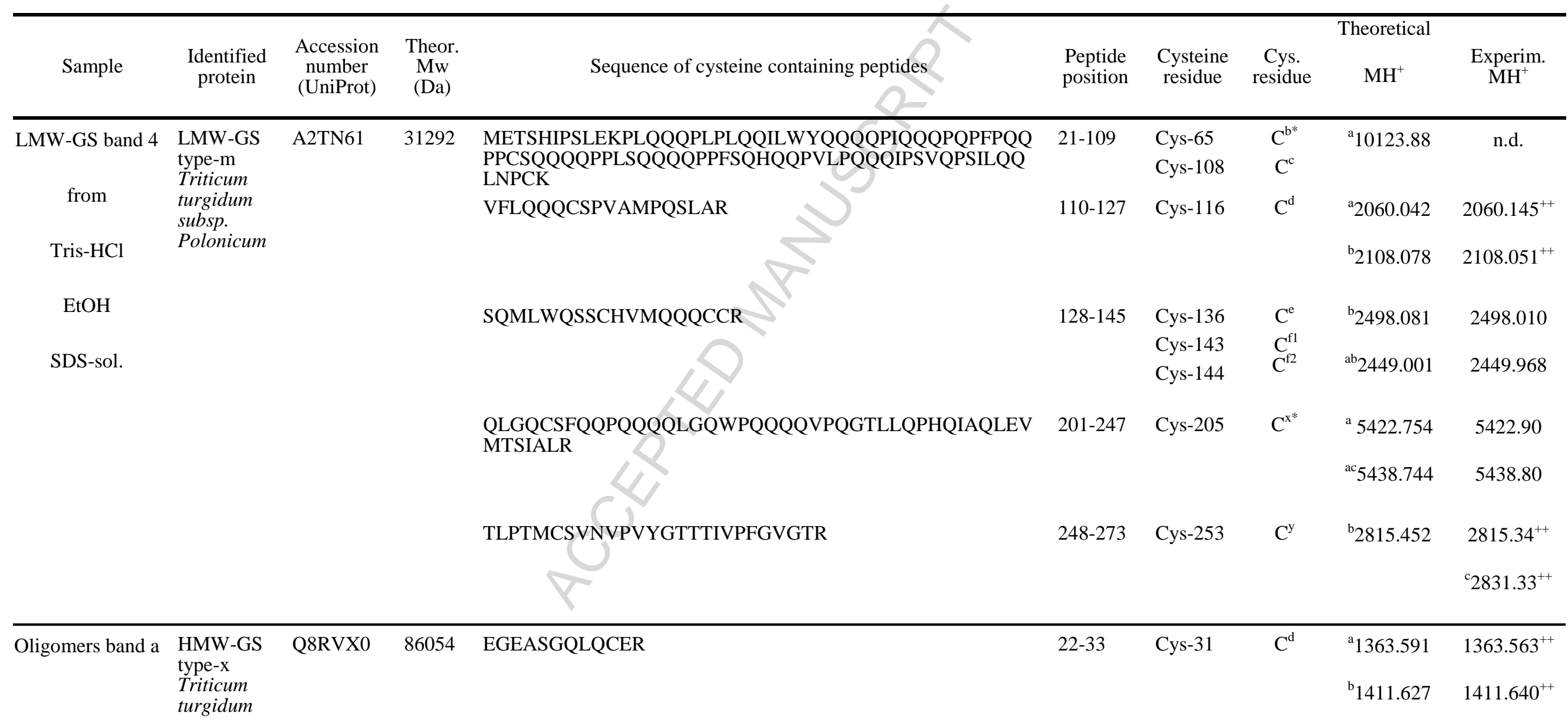


$\begin{array}{ll}\text { from } & \text { subsp. } \\ \text { Durum } & \text { AQQLAAQLPAMCR }\end{array}$

772-784 Cys-783

$\mathrm{C}^{\mathrm{z}} \quad{ }^{\mathrm{a}} 1457.735$

$1457.755^{++}$

SDS-sol.

${ }^{\mathrm{b}} 1505.772$

$1505.795^{++}$

SDS-tot.

\begin{tabular}{|c|c|c|c|c|c|c|c|c|}
\hline \multirow[t]{5}{*}{$\begin{array}{l}\text { HMW-GS } \\
\text { type-y } \\
\text { Triticum } \\
\text { aestivum }\end{array}$} & \multirow[t]{5}{*}{ B8PSA6 } & \multirow[t]{5}{*}{77334} & ELQESSLEACR & $34-44$ & Cys-43 & $\mathrm{C}^{\mathrm{b}}$ & ${ }^{\mathrm{b}} 1369.642$ & $1369.660^{++}$ \\
\hline & & & CCQQLR & $65-70$ & $\begin{array}{l}\text { Cys-65 } \\
\text { Cys-66 }\end{array}$ & $\begin{array}{l}\mathrm{C}^{1} \\
\mathrm{C}^{2}\end{array}$ & b960.454 & 960.467 \\
\hline & & & CRPVAVSQVVR & 76-86 & Cys-76 & $\mathrm{C}^{\mathrm{d}}$ & ${ }^{\mathrm{b}} 1318.741$ & $1318.753^{++}$ \\
\hline & & & $\begin{array}{l}\text { QGQQGYYPTSLQQPGQGQQPGQGQQGHCPTSPQQTGQAQ } \\
\text { QPGQGQQIGQVQQPGQGQQGYYPISLQQSGQGQQSGQGQ } \\
\text { QSGQGHQLGQGQQSGQEQQGYDNPYHVNTEQQTASPK }\end{array}$ & $576-690$ & Cys-603 & $\mathrm{C}^{\mathrm{y}}$ & ${ }^{\mathrm{a}} 12250.59$ & n.d \\
\hline & & & VQQPATQLPIMCR & 694-706 & Сys-705 & $\mathrm{C}^{\mathrm{Z}}$ & ${ }^{\mathrm{a}} 1541.793$ & $1541.794^{++}$ \\
\hline
\end{tabular}

PHQLGQGQQSGQEQQGYDNPYHVNTEQTASPK

VQQPATQLPIMCR

mature polypeptide sequence after post-translational processing $;{ }^{2}$ complete sequence $;{ }^{a}$ Cys-CAM $;{ }^{b}$ Cys-PE $;{ }^{c}$ oxidized methionine; n.d. not detected $;{ }^{++}$confirmed by MS/MS

analysis 
Highlights

- MALDI-TOF investigation was conducted on wheat storage protein from immature grains

- Newly synthesized glutenin subunits carried several reduced cysteine

- Cysteine assumed as part of disulfide bonds might be partly S-glutathionylated

- Oxidative folding of low-molecular weigh subunits is a late event 